\title{
Land Suitability Evaluation of Kubanni Floodplain for Rice Production in Zaria, Kaduna State, Nigeria
}

\author{
${ }^{*}$ A.I. Jimoh, 2 J. Aliyu, ${ }^{1}$ A.T. Saboand ${ }^{3}$ O.Y. Yusuf \\ 1Department of Geography, Gombe State University, P.M.B 127, Gombe, Nigeria. \\ 2Department of Soil Science, Ahmadu Bello University, P.M.B. 1044, Zaria, Nigeria. \\ ${ }^{3}$ Department of Geography Ahmadu Bello University, P.M.B. 1044, Zaria, Nigeria. \\ [Corresponding Author: E-mail: iajimoh@gsu.edu.ng, iajimoh@gmail.com]
}

\section{ABSTRACT}

Land suitability evaluation analysis is necessary to achieve optimum management and utilization of available land resources for sustainable agricultural crop production. The objective of this study was to determine the suitability of Kubanni floodplain for rice production in Zaria, Kaduna State, Nigeria. Qualitative and quantitative land suitability evaluation of two mapping units in Kubanni floodplain which covers an area of 11.6 ha was carried-out using the detailed soil survey method of classification. Generally, the surface soil texture was sandy loam to loam. The soil reactions were slightly acidic to neutral, organic carbon; available phosphorus and total nitrogen were rated low. The $\mathrm{CEC}\left(\mathrm{NH}_{4} \mathrm{OAc}\right)$ were medium and base saturation was rated high while EC and ESP were low. Qualitatively, soil mapping units (KBI and KBII) were currently not suitable (N1) for rice production due to limitation imposed by soil chemical properties. Quantitatively, soil mapping units (KBI and KBII) was also currently not suitable (N1) while potentially KBII was marginally suitable (S3). With proper soil fertility management, the potential of these soils can be raised to moderately suitable (S2) for rice through an increase in organic matter to improve soil structural development, drainage and aeration thereby improving the fertility of the soils.

Keywords: Qualitative, Quantitative, Suitability, Floodplains, Rice.

\section{INTRODUCTION}

Nigeria is the most populous country in Africa, with a population of over 160 million people. Its domestic economy is dominated by agriculture, which accounts for about $40 \%$ of the Gross Domestic Product (GDP) and two-thirds of the labour force (Tunii, n.d.). Agriculture supplies food, raw materials and generates household income for the majority of the people. In Nigeria today, the need for increased food production to feed the ever-increasing human population and to diversify the export base crops of the country is more recognized now than ever before. This has turned the attention of both farmer and government to the exploitation of floodplains which are believed to have more agricultural potential than the upland soils (Esu, 1999). Land suitability evaluation is the process of making predictions of land performance over time based on specific types of uses (Rossiter, 1996). This assessment is always carried out separately for each category of land use (Reshmidevi et al.,
2009). Land evaluation can tell farmers how suitable their land is in terms of soil limitations to specified land use and management practices. Soil suitability classifications are therefore based on knowledge of crop requirements, prevailing soil conditions and defined soil management. In other words, soil suitability classifications specify to what extent soil conditions match crop requirements under defined input and management circumstances (FAO, 1976 cited in Jimoh, 2015). The suitability looks at the limitations imposed by soil properties, landform and other features which do not form a part of the soil but may have a significant influence on using the soil. From the basic soil requirements of crops, a number of soil characteristics are directly related to crop yield performance. The function of land evaluation is to bring about an understanding of the relationships between the condition of the land and the uses to which it is put to and to present planners with comparisons and promising alternative options. 
The food sub-sector of Nigerian agriculture parades a large array of staple crops, this includes sorghum, maize, millet, rice, wheat etc. Of all the staple crops, rice has risen to a position of preeminence. Rice (Oryza sativa) as a cereal grain is the most important staple foods for a large part of the world's human population. Rice is the grain with the second-highest worldwide production, after maize (FAOSTAT, 2005), rice is the most important grain with regard to human nutrition and caloric intake, providing more than one-fifth of the calories consumed worldwide by the human species (Smith, 1998). Rice which is the most consumed grain is short in supply, and there is growing demand to increase its production in Zaria environ. They are widely regarded as a superior food, which until recently was mainly consumed by city dwellers and middle and higher income earners (Dawam, 2000 cited in Aondoakaa and Agbakwuru, 2012). It is in this direction that a land suitability evaluation study is relevant.

De Detta (1981) as cited in Jimoh (2015) maintained that land data should be made available and understandable to the users by providing interpretative ratings for specific land use. The land qualities and land use requirements should be matched to enable farmers to maximize output in agricultural production by identifying the land qualities and the requirements for various lands for effective management. Thus, the land suitability studies will assist in identifying soils for optimum yields for rice in Zaria. Therefore, information is needed on soil qualities and climatic conditions of the area to ascertain the suitability of the soil for rice cultivation. Studies on land evaluation are few in Nigeria as reported by Atofarati et al. (2012) that the major factor limiting agricultural productivity in the country is inadequate information on land characteristics. A number of studies have been carried out in the country to enrich our soil databank; this includes Oluwatosin (2005) who assessed suitability of some land in Northwestern Nigeria for rainfed crop production using a qualitative land evaluation method. The study revealed that all the soils were currently not suitable (N1) for cereals but were marginally suitable (S3) for grain legumes. The major limitations were nutrient availability (f) which cut across all the soil while erosion hazard and drainage were a major limitation in the upland and valley bottom respectively. In addition, Lawal et al. (2012) evaluated the suitability of soils of lower river Oshin floodplains in Kwara State, Nigeria for rainfed arable crops using the FAO land suitability evaluation method. They reported that all the soil units were moderately suitable (S2) for maize production while for rice production, the area was marginally suitable (S3) with topography, soil texture and soil fertility being the major limitation. Despite the importance of land evaluation on the sustainable management of land and for enhanced crop production, specific soil suitability studies such as suitability assessment for rice production have not been properly documented in literature. This study attempts to contribute to existing knowledge as well as fill the locational gap in knowledge on soil suitability assessment in Zaria.

\section{MATERIALS AND METHODS Description of the study area}

Kubanni floodplains, Zaria, Kaduna State (11006'50"N - 7040'22"E) is characterized by Northern Guinea Savanna vegetation type. The area is intensively cultivated to an array of crops such as maize, rice, cowpea, onion and tomato. The length of growing period is $150-180$ days (Yakubu, 2004). Zaria lies within a region which has a tropical Savanna (Aw) climate type with distinct wet and dry season (Kowal and Knabe, 1972). It is characterized by long dry season from November through March while the wet season from April to October with a mean annual rainfall of $1100 \mathrm{~mm}$. The temperature fluctuates within a range from $22^{\circ} \mathrm{C}$ during cold nights to over $38^{\circ} \mathrm{C}$ during the hot days. The relative humidity during dry season is about $15 \%$ and reaches up to $60 \%$ during the rainy season (Kowal and Knabe, 1972). Geologically, the area lies within the high plains of Northern Nigeria characterized by 
landforms which consist of inselbergs and pediment landscape overlying the basement complex which is nearly level to gently undulating plains (Yakubu, 2004).

\section{Soil Sampling}

A detailed soil survey using rigid-grid method $(100 \mathrm{~m} \times 100 \mathrm{~m})$ on 11.6 ha land was carried out. Soil units were mapped out based on colour, texture, drainage and depth; two modal profile pits were dug and examined according to Soil Survey Staff (2010) procedure. Bulk soil samples were collected from various genetic horizons identified within the profile pits of each soil unit. The samples were air-dried, sieved with a $2 \mathrm{~mm}$ sieve size and analyzed in the laboratory for physical and chemical properties.

\section{Laboratory analyses}

Particle size distribution was determined by the hydrometer method (Gee and Bauder, 1979). Soil $\mathrm{pH}$ was measured in water using glass electrode pH meter (Agbenin, 1995). Organic carbon was determined by the dichromate wet oxidation method of Walkley and Black (Nelson and Sommers, 1982). The cation exchange capacity (CEC) was determined using the ammonium acetate method (Agbenin, 1995). Base saturation was calculated as the sum of total exchangeable bases divided by cation exchange capacity $\left(\mathrm{NH}_{4} \mathrm{OAc}\right)$ (Agbenin, 1995). Available $\mathrm{P}$ was determined using Bray 1 method (IITA, 1979). Total $\mathrm{N}$ was determined by the Kjeldahl method (Bremner and Mulvaney, 1982). Exchangeable bases (calcium $(\mathrm{Ca})$, magnesium $(\mathrm{Mg})$, potassium $(\mathrm{K})$ and sodium $(\mathrm{Na})$ in the soil were determined using the ammonium acetate extract from the CEC determination. Sodium and $\mathrm{K}$ were determined using flame photometer while $\mathrm{Ca}$ and $\mathrm{Mg}$ was determined using atomic absorption spectrometer. Electrical conductivity was determined using Wheatstone bridge method (Agbenin, 1995) while exchangeable sodium percentage (ESP) was calculated as the percentage sum of total exchangeable sodium divided by cation exchange capacity $\left(\mathrm{NH}_{4} \mathrm{OAc}\right)$ (Agbenin, 1995).

\section{Land Evaluation \\ Qualitative land suitability evaluation for rice production}

Qualitative or Non-parametric method of land suitability evaluation for rice was carried out using the FAO method (FAO, 1983) (Table 1). Key environmental factors considered in the evaluation were climate (annual rainfall, temperature), topography (slope) and soils. The identified soil units were placed in suitability classes by matching their characteristics with requirements of the test crop. The most limiting characteristic dictate overall suitability for each soil unit using limiting condition procedure. The suitability of each factor for respective soil unit was classified as highly suitable (S1), moderately suitable (S2), marginally suitable (S3) or not suitable (N).

\section{Quantitative land suitability evaluation for rice production}

In quantitative (parametric) method of land evaluation, each limiting characteristic was rated as follows: S1 (95), S2 (85), S3 (60), N (40). The index of productivity for each soil mapping units was calculated using Ogunkunle (1993) modified equations:

$I P=A \times \sqrt{ }(B / 100 \times C / 100 \times D / 100 \times E / 100 \times$ $F / 100)$.

Where $A=$ overall lowest characteristic rating of all land quality groups (Nutrient availability), B, C, $D$, and $E$ are lowest characteristic ratings for their respective land quality group. The land characteristic was grouped into the following land qualities; climate (c), soil physical property (p), wetness (w), Nutrient availability (f) and Salinity (S). The suitability classification was done separately for each soil unit identified in the study area.

\section{Productivity index}

Potential Index of Productivity (IPp): In computing the IPp, properties that are not easily altered like cation exchange capacity, base saturation, $\mathrm{pH}$ and organic matter were used as part of the 
fertility $(f)$ group while the easily altered chemical properties like exchangeable $\mathrm{K}, \mathrm{Ca}$, available $\mathrm{P}$, and total $\mathrm{N}$ were not part of the calculation.

Current Index of Productivity (IPc): In this case, both the easily altered chemical properties like exchangeable $\mathrm{K}, \mathrm{Ca}$, available $\mathrm{P}$ and total $\mathrm{N}$, as well as those used for IPp, were used for the calculation of the IPc.

\section{RESULT AND DISCUSSION}

\section{Land Characteristics of the Study Area}

Two soil units were delineated and denoted as $\mathrm{KBI}$ and $\mathrm{KBII}$ based on soil colour, texture, drainage and depth. Land qualities of the soils units are shown in Table 2. The soils were rated using the critical limits recommended by Malgwi (2007). Soil units $\mathrm{KBI}$ was deep $(>145 \mathrm{~cm})$, imperfectly drained, yellowish brown (10YR5/4) in colour, texture varied from sandy loam to loam and covered an area of 7.9 ha. Soil units KBII was also deep to very deep $(>170 \mathrm{~cm})$, imperfectly drained, colour varied from dark yellowish brown (10YR4/6) to brownish yellow (10YR6/6), dominated by loam texture and covered an area of 3.7 ha.

Table 1: Factor of suitability rating for rice

\begin{tabular}{|c|c|c|c|c|}
\hline $\begin{array}{l}\text { Land Characteristicl } \\
\text { diagnostic factor }\end{array}$ & $\begin{array}{c}\text { S1 } \\
95-85\end{array}$ & $\begin{array}{c}S 2 \\
65-60\end{array}$ & $\begin{array}{c}S 3 \\
60-20\end{array}$ & $\begin{array}{c}N \\
<20\end{array}$ \\
\hline \multicolumn{5}{|l|}{ Climate } \\
\hline Rainfall (mm) & $800-1200$ & $700-800$ & $600-700$ & $<600$ \\
\hline Temperature $\left({ }^{\circ} \mathrm{C}\right)$ & $24-28$ & $22-24,30-32$ & $18-22,32-35$ & $<18,>35$ \\
\hline \multicolumn{5}{|l|}{ Land/soil physical property } \\
\hline Slope (\%) & $0-1$ & $1-2$ & $2-4$ & $>4$ \\
\hline Soil depth $(\mathrm{cm})$ & $>75$ & $50-75$ & $25-50$ & $<25$ \\
\hline Soil Texture & C, SiC, CL & SC, SiC, SiL & SL, L, SCL & S, LS \\
\hline Volume of coarse fragment & $<15$ & $<35$ & $<55$ & $\begin{array}{l}<55 \\
\text { Poor, very }\end{array}$ \\
\hline Drainage & Well & Moderately Well & Imperfect & poor \\
\hline \multicolumn{5}{|l|}{ Nutrient availability (topsoil) } \\
\hline $\mathrm{pH}$ & $5.0-6.0$ & $6.0-7.0$ & $7.0-8.0$ & $>8$ \\
\hline Organic Carbon ( $\left.\mathrm{gkg}^{-1}\right)$ & $20-40$ & $10-20$ & $5-10$ & $<5$ \\
\hline Total Nitrogen $\left(\mathrm{gkg}^{-1}\right)$ & $>2$ & $1-.2$ & $0.5-1$ & $<0.5$ \\
\hline Available P $\left(\mathrm{mgkg}^{-1}\right)$ & $>40$ & $20-40$ & $10-20$ & $<10$ \\
\hline Exchangeable K (cmolkg-1) & $>0.2$ & $0.1-0.2$ & $<0.1$ & $<0.1$ \\
\hline $\mathrm{CEC}\left(\mathrm{cmol}(+) \mathrm{kg}^{-1}\right)$ & $>25$ & $13-25$ & $6-12$ & $<6$ \\
\hline Base Saturation (\%) & $>75$ & $50-75$ & $30-50$ & $<30$ \\
\hline \multicolumn{5}{|l|}{ Salinity and Sodicity } \\
\hline Salinity EC (dS/m) & $<3$ & $3-6$ & $6-10$ & $>10$ \\
\hline Sodicity ESP (\%) & $<15$ & $15-40$ & $40-50$ & $>50$ \\
\hline
\end{tabular}


Generally, soil depth of the mapping units would permit crop root proliferation and elongation since water table was deep enough not to constitute hindrance to root development. The brown to gray colour could be attributed to imperfectly drainage condition of the soils, indicating that $\mathrm{Fe}^{3+}$ is reduced to $\mathrm{Fe}^{2+}$ giving the soil matrix a grayish colour. The imperfect drain condition was as a result of the valley floor position which receives runoff of water and sediments from the upland and high water table of the units (Jimoh, 2015). Atofarati et al. (2012) reported similar findings on soils of toposequence in Ile-Oluji, Ondo State, Nigeria. The two soil units were dominated by grain structure which may be as a result of low content of clay in the soils which acted as binding agent.

The soil pH was slightly acidic to neutral (6.4-6.9) which is within the $\mathrm{pH}$ requirement for most arable crops (Brady and Weil, 1999). Generally, organic carbon (O.C) $(3.5-4.9 \mathrm{~g} / \mathrm{kg})$, available phosphorus (Ap) $(4.47-6.22 \mathrm{mg} / \mathrm{kg})$ and total nitrogen (TN) $(0.11-0.14 \mathrm{~g} / \mathrm{kg})$ was rated low while CEC value of $(8.4$ - 8.15) was rated medium according to Malgwi (2007). The medium level of the CEC might be a reflection of the intensity of weathering of parent material from which the soil evolved. Base saturation $\left(\mathrm{NH}_{4} \mathrm{OAc}\right)$ of the surface soils were rated medium to high $(67-87 \%)$ in all the units, similar result was reported by Atofarati et al. (2012). FAO (1999) reported that soils with base saturation of $>50 \%$ are regarded as fertile soils while soils with less $<50 \%$ are infertile. Based on FAO classification, the soils were classified fertile soils. The EC value of soil was rated very low $\left(<4 \mathrm{dSm}^{-1}\right)$ which indicates none saline (electrical conductivity class). Exchangeable Soil Percentage (ESP) of soil unit KBI was rated low $(<15)$ while soil $\mathrm{KBII}$ was rated higher $(>15)$ the critical limit for sodicity (Brady and Weil, 2002). This implies that this soil unit is sodic i.e high in $\mathrm{Na}^{+}$content and this could significantly affect crop production. Sodic soils are usually more dispersed, less permeable to water and are of poor tilth, usually plastic and sticky when wet and are more prone to form clods and crust on drying (Babalola et al., 2011). For improved crop yields, soil fertility restoration measures which include the use of inorganic and organic manure to improve the soil physical and chemical constraints should be adopted.

Table 2: Characteristics of the soil mapping units

\begin{tabular}{|c|c|c|}
\hline $\begin{array}{l}\text { Land } \\
\text { Characteristic }\end{array}$ & KBI & KBII \\
\hline \multicolumn{3}{|l|}{ Climate } \\
\hline $\begin{array}{l}\text { Mean Annual } \\
\text { Rainfall (mm) }\end{array}$ & 1004 & 1004 \\
\hline Temperature $\left({ }^{\circ} \mathrm{C}\right)$ & 26 & 26 \\
\hline \multicolumn{3}{|c|}{ Land/soil physical property } \\
\hline Slope (\%) & $0-2$ & $0-2$ \\
\hline Soil Depth (cm) & $>160$ & $>150$ \\
\hline Soil Texture & SL,L/SL & SL \\
\hline Drainage & $\begin{array}{l}\text { Imperfectly } \\
\text { Drained }\end{array}$ & $\begin{array}{l}\text { Imperfectly } \\
\text { Drained }\end{array}$ \\
\hline \multicolumn{3}{|c|}{ Nutrient availability (topsoil) } \\
\hline $\mathrm{pH}\left(\mathrm{H}_{2} \mathrm{O}\right)$ & 6.9 & 6.4 \\
\hline Organic Carbon (gkg-1) & 3.5 & 4.9 \\
\hline Total Nitrogen $\left(\mathrm{gkg}^{-1}\right)$ & 0.11 & 0.14 \\
\hline Available P $\left(\mathrm{mgkg}^{-1}\right)$ & 4.47 & 6.22 \\
\hline $\begin{array}{l}\text { Exchangeable } \mathrm{K}(\mathrm{cmol} \\
\left.\mathrm{kg}^{-1}\right)\end{array}$ & 0.21 & 0.27 \\
\hline $\mathrm{CEC}\left(\mathrm{cmol}(+) \mathrm{kg}^{-1}\right)$ & 8.4 & 8.15 \\
\hline Base Saturation (\%) & 87 & 67 \\
\hline \multicolumn{3}{|l|}{ Salinity and Sodicity } \\
\hline Salinity EC (dS/m) & 0.07 & 0.08 \\
\hline Sodicity ESP (\%) & 18 & 6 \\
\hline
\end{tabular}

$\mathrm{CL}=$ Clay loam, $\mathrm{L}=$ loam, $\mathrm{SL}=$ sandy loam, $\mathrm{LS}=$ loamy sand, $\mathrm{LCM}=$ loamy coarse sand, $\mathrm{CS}=$ coarse sand

Source: Fieldwork (2014) 


\section{Qualitative land suitability classification for rice production}

A summary of land qualities/land characteristics of the study area is shown in Table 2. The assessment ratings resulting from matching of land qualities and the requirements for rice is presented in Table 1 using the FAO (1983) suitability ratings. Soil units $\mathrm{KBI}$ and $\mathrm{KBII}$ have effective soil depth $>100 \mathrm{~cm}$ and thus were rated highly suitable (S1) for rice. Mean annual rainfall and temperature were considered highly suitable (S1). On the basis of soil texture, soil units $\mathrm{KBI}$ and $\mathrm{KBII}$ which were sandy loam to loam, overlaying loam was marginally suitable (S3) for rice. The slope of $<2 \%$ made soil mapping units $\mathrm{KBI}$ and $\mathrm{KB} I \mathrm{ll}$ soil units moderately suitable (S2). However, slope of $<3 \%$ may favour mechanical operation (Fasina and Adeyanju, 2007). The entire soil units were imperfectly drained hence rated marginally suitable (S3).

Regarding soil reaction $(\mathrm{pH})$, soil mapping units $\mathrm{KBI}$ and $\mathrm{KBII}$ were moderately suitable (S2). Considering nutrient retention ability (CEC), soil units $\mathrm{KBI}$ and $\mathrm{KBIl}$ were marginally suitable (S3). Soil units KBI and KBII were highly suitable (S1) with regard to exchangeable K. Soil mapping units KBI was highly suitable (S1) while KBII was moderately suitable (S2) with regard to percent base saturation (BS). Soil units KBI was currently not suitable (N1) while KBII was marginally suitable (S3) with respect to organic $C$ content. With regard to total nitrogen and available phosphorus both soil units (KBI and $\mathrm{KBII}$ ) were currently not suitable (N1). All the soil units were highly suitable (S1) with regards to salinity and sodicity status (Table 3 ). Soil mapping units $\mathrm{KBI}$ and KBII were currently not suitable (N) (Table 3 ) for rice production due to low organic carbon, total nitrogen and available phosphorus contents. Ogunkule (1993); Olaleye (2002) and Oluwatosin (2005) also reported that soil fertility is the major limitation to the suitability of Nigeria soils. The overall suitability of the Kubanni floodplains for rice production was classified into the order not suitable (N1), class currently not suitable (N1), and subclass $f$ (fertility) while the units were f-
1 (fertility) (Table 3). Soil mapping unit $\mathrm{KBI}$ and KBII were classified as N1f-1 which represents a deficiency of organic carbon, total nitrogen and available $P$ for rice production at the unit level of classification.

\section{Quantitative land suitability classification for rice production}

In the parametric method of land evaluation, the soils of all the soil units were classified as currently not suitable (N1) with suitability aggregate score of less than 24 , based on current productivity index and currently not suitable (N1) in KB I and marginally suitable (S3) in KB II base on the potential productivity index (Table 4). The result of the current parametric and current non-parametric suitability evaluation shows mutual relationship. Thus, this indicates that both evaluation methods were correlated as their suitability classes were similar except for potential suitability of soil unit KBII.

\section{Overall Qualitative and Qualitative Suitability of all the soil units}

The crop requirement (Table 1) and the soil qualities (Table 2) in the study area were matched with rating of land use requirement for rice. Soils of all the soil units were rated low with respect to organic carbon, total nitrogen and available phosphorus which could significantly reduce productivity. Based on the climatic condition, all the units were highly suitable and based on soil factor, $\mathrm{KBI}$ and $\mathrm{KBII}$ were classified into order $\mathrm{N}$, class $\mathrm{N} 1$ (currently not suitable), subclass $f$ (fertility) while units were $f-1$ (fertility). Qualitatively, both parametric and non-parametric method of evaluation of floodplain soil of Kubanni showed that soil unit KB1was ranked N1 (22.80) and N1f-1 (Table 4) for both current and potential productivity. Fertility status (organic carbon, total nitrogen and available P) was the factor limiting the suitability of the soil for rice production. Soil unit KBII was evaluated as being marginally suitable (S3) with aggregate suitability score of greater than 25 and less than 45 (Table 4) for floodplain (wetland) rice production. 


\section{Nigerian Journal of Basic and Applied Science (June, 2018), 26(1): 46-54}

Table 3: Matching land use requirement with floodplain quality for rice

\begin{tabular}{|c|c|c|c|}
\hline \multirow{2}{*}{$\begin{array}{l}\text { Land Characteristic / } \\
\text { diagnostic factor }\end{array}$} & \multirow{2}{*}{ Unit } & \multicolumn{2}{|c|}{ Soil Mapping Units } \\
\hline & & $\mathrm{KBI}$ & KBII \\
\hline \multicolumn{4}{|l|}{ Climate (c) } \\
\hline Rainfall ® & $(\mathrm{mm})$ & S1 (95) & S1 (95) \\
\hline Temperature (t) & $\left({ }^{\circ} \mathrm{C}\right)$ & S1 (95) & S1 (95) \\
\hline \multicolumn{4}{|c|}{ Land/soil physical property (p) } \\
\hline slope (s) & $(\%)$ & S2 (85) & S2 (85) \\
\hline Soil depth (d) & (cm) & S1 (95) & S1 (95) \\
\hline Soil Texture (a) & & S3 (60) & S3 (60) \\
\hline \multicolumn{4}{|l|}{ Soil wetness (w) } \\
\hline Drainage $(\mathrm{m})$ & & S3 (60) & S3 (60) \\
\hline \multicolumn{4}{|c|}{ Nutrient availability (topsoil) (f) } \\
\hline $\mathrm{pH}$ & $\left(\mathrm{H}_{2} \mathrm{O}\right)$ & S2 (85) & S2 (85) \\
\hline Organic Carbon (0) & $\left(\mathrm{gkg}^{-1}\right)$ & $N(40)$ & S3 (60) \\
\hline Total Nitrogen (n) & $\left(g_{k g}^{-1}\right)$ & $\mathrm{N}(40)$ & $\mathrm{N}(40)$ \\
\hline Available P (p) & $\begin{array}{l}\text { (mgkg- } \\
\text { 1) }\end{array}$ & $\mathrm{N}(40)$ & $N(40)$ \\
\hline Exchangeable K (k) & $\left(\mathrm{cmolkg}^{-1}\right)$ & S1 (95) & S1 (95) \\
\hline $\operatorname{CEC}(c)$ & $\left(\mathrm{cmolkg}^{-1}\right)$ & S3 $(60)$ & S3 (60) \\
\hline Base Saturation (n) & $(\%)$ & S1 (95) & S2 (85) \\
\hline \multicolumn{4}{|c|}{ Salinity and Sodicity (s) } \\
\hline Salinity EC (e) & $d S / m$ & S1 (95) & S1 (95) \\
\hline Sodicity ESP $(e)$ & $(\%)$ & S1 (95) & S1 (95) \\
\hline
\end{tabular}

Table 4. Suitability aggregate score and classification of the soil units

\begin{tabular}{lclll}
\hline Soil unit & \multicolumn{2}{c}{ Parametric } & \multicolumn{2}{c}{ Non-parametric } \\
& Current & Potential & Current & Potential \\
\hline KB1 & N1 $(22.80)$ & N1 $(22.80)$ & N1f-1 & N1f-1 \\
KB11 & N1 (22.80) & S3 (34.30) & N1f-1 & S3f-1 \\
\hline
\end{tabular}

Aggregate Suitability Class Score: $100-75=\mathrm{S1}, 74-50=\mathrm{S} 2,49-25=\mathrm{S3}, 24-15=\mathrm{N} 1$ and $<14=\mathrm{N} 2$ Subclass indicator: Nutrient avaliability (f).

\section{CONCLUSION}

Climate, soil depth, salinity and sodicity factors were highly suitable for rice cultivation, slope and soil reaction $(\mathrm{pH})$ were moderately suitable. However, soil organic carbon, total nitrogen and available phosphorus rendered all the soil units currently unsuitable (N1) for the cultivation of rice by non-parametric method of evaluation using the current productivity method. KBII was evaluated as marginally suitable (S3) for rice production using the parametric method of investigation (potential productivity). Low levels of organic matter, total nitrogen and available phosphorus are the major constraints of these soils and these can be improved by increasing the organic matter level through the incorporation of organic 
residues such as farmyard manure, plant residues, and household refuse. The organic matter can improve soil structural development, drainage and aeration thereby improving the fertility of the soils for sustainable rice production.

\section{REFERENCES}

Agbenin, J.O. (1995). Laboratory Manual for Soil and Plant Analysis. Department of Soil Science, Ahmadu Bello University Zaria, Kaduna State.

Aondoakaa, S.C. and Agbakwuru, P.C. (2012). An Assessment of land Suitability for Rice Cultivation in Dobi, Gwagwalada Area Council, FCT - Nigeria. Ethiopian Journal of Environmental Studies and Management, 5(4): 444-451.

Atofarati, S.O., Ewulo B.S., Ojeniyi S. 0 (2012). Characterization and classification of soils on two toposequence at Ile-Oluji, Ondo State, Nigeria. International Journal of Agri-Science, 2(7): 642-650.

Babalola T.S., Oso, T., Fasina, A.S. and Godonu, K. (2011). Land Evaluation Studies of two Wetland Soils in Nigeria. International Research Journal of Agricultural Science and Soil Science, 1(6): 193-204.

Brady, N.C. and Weil, R.C. (2002). The Nature and Properties of Soils.13th edition. Pearson Education. India. 960pp.

Brady. N.C. and Weil R.R. (1999). The Nature and Properties of Soils. $12^{\text {th }}$ ed. Prentice Hall, Upper Saddle River, New York. $881 \mathrm{pp}$.

Bremner, J.M., and Mulvaney, C.S., (1982). Nitrogen - Total. p. 595-624. In: Page A., L., Miller, R., H. and Keeney, D., R., (eds.) Methods of Soil Analysis. Part 2.Chemical and Microbiological Properties.2nd ed. Agron. Monogr. 9. ASA and SSSA, Madison, WI.

Esu, I.E (1999). Fundamentals of Pedology. Stirling-Horden, Ibadan Nigeria. 87-98pp

FAO (1999).World Reference Base for Soil Resources. World Soil Resources Report, 84. Food and Agricultural
Organisation of the UN, Rome, Italy, $161 \mathrm{pp}$.

FAO (1976). A framework for land evaluation, Soil Bulletin, 32, FAO, Rome.

FAO (1983).Guidelines: Land Evaluation for Rain-fed Agriculture. Soil Bulletin No 52, Food and Agriculture Organization, Rome, $237 \mathrm{pp}$.

FAOSTAT (2005). Faostat-Online: http://faosts.fao.org. FAOSTAT. http://faostat.fao.org/site/567/DesktopDef ault.aspx. Retrieved December 26, 2006.

Fasina, A. S. and Adeyanju A. (2007). Comparison of three Land Evaluation Systems in Evaluating the Predictive Value of some selected soils in Ado-Ekiti, Southwest Nigeria. Journal of Soil Science, 17:113-119.

Gee, G.W. and Bauder, J.N. (1979). Particle Size Analysis by Hydrometric Method; A Simplified Method For Routine Textural Analysis And Sensitivity Test of Mineral Parameters, Soil Science Society, American Journal, 43: 1004-1007.

IITA (1979). Selected Methods for Soil and Plant Analysis. $2^{\text {nd }}$ edn., International Institute of Tropical Agriculture, Ibadan, Oyo State, Nigeria, Pages: 70.

Jimoh, A. I. (2015). Characterization and Suitability Evaluation of Kubanni Flood plains and Adjoining Upland Soils for Rice and Maize Production in Zaria area of Kaduna State. Nigeria. Unpublished M.Sc., thesis, Department of Geography, ABU Zaria

Kowal, D. and Knabe, D.J. (1972). An Agroclimatological Atlas of the Northern State of Nigeria. Ahmadu Bello Univ. press, Zaria, Nigeria.

Lawal, B. A., Ojanuga A. G., Noma, S. S., Adeboye, M.K.A., Dikko, A.U. and Singh, A. (2012). Suitability Evaluation of Soils of Lower River Oshin Floodplain, Kwara State, Nigeria for Rain-Fed Arable Crop Cultivation. Nigerian Journal of Soil and Environmental Research, 10:71 - 78. 


\section{Nigerian Journal of Basic and Applied Science (June, 2018), 26(1): 46-54}

Malgwi W.B. (2007). Soil Survey: Soil Analytical

Data Interpretation for Land

Management. Paper presented at

Training Workshop in Soil Survey and

Land Evaluation Methodology for Federal

Department of Agriculture and Land

Resource Staff in Kaduna.

Nelson, M.J. and Sommers, L.E. (1982). Total Carbon, Organic Carbon and Organic Matter. In: Page, L.A., Miller, R.H. and Keeney, D.R. (eds), Methods of Soil Analysis, pp. 539-579. Part 2. Chemical and Microbiological Methods (2nded). American Society of Agronomy. Madison, W.I

Ogunkule, A.O. (1993). Soil in Land Suitability Evaluation: An example with oil palm in Nigeria. Soil use Management, 9:1.

Olaleye, A.O., Ogunkunle, A.O., Sahrawat, K.L, Osiname, O.A. and Ayanlaja, S.A. (2002). Suitability Evaluation of Selected Wetland Soils in Nigeria for Rainfed Rice Cultivation. Tropicultura, 20(3): 97-103

Oluwatosin, G.A. (2005). Land Suitability Assessment in Continental Grits of Northwestern Nigeria for Rainfed Crop Production. West African Journal of Applied Ecology, 7:53-67.

Reshmidevi, T.V., Eldho, T.l., and Jana, R., (2009). A Gis-Integrated Fuzzy Rule-
Based Inference System for Land Suitability Evaluation in Agricultural Watersheds. Agr. Syst. 101(1-2):101109.

Rossiter, D.G., (1996). A Theoretical Framework for Land Evaluation (with discussion). Elsevier Scientific, Geoderma, 72(3-4): 165-202.

Smith, B. D. (1998). The Emergence of Agriculture. Scientific American Library, A Division of HPHLP, New York. ISBN 07167-6030-4.

Soil Survey Staff (2010). Keys to Soil Taxonomy. $11^{\text {th }}$ Edition. USDA/NRCS, Washington, DC.

Tunji, A. (n.d.) An Overview of the Nigerian Rice Economy. A Presentation at the Nigerian Institute of Social and Economic Research (NISER) by Director, Agriculture and Rural Development Department. Retrieved October, 8, 2017 from

http://unep.ch/etb/etp/events/Agriculture/ nigeria.pdf.

Yakubu Samuel (2004). Assessment of soil changes under different land uses in Zaria area, Northerm Nigeria. Unpublished M.Sc., thesis Department of Geography, ABU Zaria. 